\title{
THE RESPONSE OF STATE LEGISLATION TO HISTORIC PRESERVATION
}

\author{
Paul E. Wirson* and H. James Winkier II
}

\section{INTRODUCTION}

The protection and preservation of places of historic, cultural, and natural interest are activities particularly appropriate to state and local governments. The charm of America is accentuated by diversity-diversity of history, geography, economy, and the varied ethnic origins and cultural concerns and values of its people. Few landmarks have significance that is truly national in character. Rather, most have special relationships to particular places or people whose unique interests they reflect. Standards and procedures for historic preservation are thus necessarily related to state and local objectives and can be implemented most feasibly through governmental action on state and local levels. Moreover, the states are the repositories of the powers of the government most useful in achieving preservation objectives-the police power, the power of taxation, and the power of eminent domain. Awareness of the need for the state and local initiative is reflected in much of the recent preservation legislation enacted by the Congress. ${ }^{\text {. }}$

\section{Patterns in State Preservation Legislation}

Few, if any, state legislatures have demonstrated a long continuing concern for preservation of cultural landmarks. American life has emphasized the new-new ways, new ideas, new things. The old has often been the subject of indifference or disdain. Too much state control of historic properties has been thought to deviate from the traditional American concept of the role of government in society. Economic considerations are often overriding deterrents to preservation legislation. Hence, much of the activity aimed at the preservation of places and objects of historic interest has been initiated and carried forward by civic-minded individuals and private organizations. While activity of this kind is often rewarding to the community and results in the preservation of objects of veneration, in other cases the objectives of historic preservation have been obscured by short-range economic motives. The accelerated rate of destruction of historic landmarks in the twentieth century has demonstrated the need for greater governmental participation and has produced accelerated activity by state legislatures. Thus, during the past few decades patterns in state laws aimed at historic preservation have begun to emerge.

\footnotetext{
- Kane Professor of Law, the University of Kansas.

+ Senior law student, the University of Kansas School of Law.

1 National Historic Preservation Act, I6 U.S.C. $\$ 470$ et seq. (I970); 42 U.S.C. $\$ 1500$ et seq. (I970).
} 
Generalizations about state preservation legislation are difficult. A variety of techniques are employed to accomplish a wide range of objectives. A few state constitutions deal specifically with historic preservation, ${ }^{2}$ and all of the states have statutes of some kind relating to the subject. Much state legislation is limited in scope, providing only for the maintenance of publicly-owned landmarks, including battlefields, historic buildings, statues, and other sites. ${ }^{3}$ Title to such property may be vested in the state or may be conferred upon a state-related organization which is authorized to accept gifts and bequests and otherwise acquire property in the name of the state. ${ }^{4}$ The structure and powers of state agencies responsible for preservation are usually defined by the legislature. Landmark preservation functions may be vested in a central state agency or responsibility may be diffused among several divisions of government; ${ }^{5}$ in still other instances such functions may be assigned to quasi-independent entities. ${ }^{6}$ The powers conferred vary considerably from state to state. Some agencies have only advisory roles, ${ }^{7}$ while others have plenary powers to acquire and administer property of historic interest. ${ }^{8}$

In addition to providing a structure and standards for preservation services on a state level, the state legislature has an important role in declaring and defining the powers of local governments to engage in historic preservation. The greatest threats to historic landmarks occur in urban areas where the forces that produce physical change are most dynamic. In a framework of particular local needs, coupled with overriding local concerns and the American tradition of local autonomy, the legislature's most appropriate response may be in the form of enabling legislation empowering municipalities and other local governments to acquire, maintain, and control historic properties.

Legislation providing for the public ownership and management of historic property does not provide an adequate response to current needs for landmark preservation. For many reasons, widespread public ownership of historic property is not feasible. Publicly-owned property may be expensive to acquire and maintain. It is no longer a source of tax revenue. It is likely to be removed from economically productive uses. It is necessarily limited in scope and is hardly a feasible technique for the control of neighborhoods or areas, particularly in urban communities.

\footnotetext{
${ }^{2}$ MAss. Const. amend. II and Mo. Consr. art. III, $\$ 48$, authorize general preservation laws. LA. CoNst. art XIV, $\$ 22 \mathrm{~A}$, was adopted specifically to preserve the French Quarter or "Vieux Carre" in New Orleans, Louisiana. Two other states have constitutional provisions which affect historic landmarks: TEx. Const. art. I6, $\{39$, authorizes legislative appropriations to preserve historical memorials, and the Dex. Consr. art. II, $\S 25$, grants special zoning powers to the first settlement in the state, New Castle County.

${ }^{3}$ J. Morrison, Historic Preservation Law 7 (I965) [hereinafter cited as Morrison].

Id.

Id. at 8.

${ }^{6}$ Many state historical societies, having corporate indentities separate from the state, have prescrvation functions assigned by state law, such as Ohio and Kansas.

${ }^{7}$ Morrison 8.

${ }^{8}$ Id. For an example of this type of legislation, see KAN. STAT. ANN. $\$ 75^{-270 r}$ (1969) declaring: "The society may acquire property, real or personal, by gift, bequest or otherwise, in any amount, and upon such conditions as its executive committee may deem best for its interests."
} 
Hence, the most significant role of state legislation and the greatest opportunity for innovative policy-making probably lies in the area of providing such services, standards, controls, and incentives as will encourage the practice of preservation techniques by private owners and users of historic property. The powers to be conferred and the manner of their execution will be determined with reference to the objectives intended to be achieved.

Certain basic considerations must necessarily be confronted by drafters of state preservation legislation. The following enumeration, which does not purport to be exhaustive, suggests a few questions that must be resolved in any serious legislative effort to respond to the needs of historic preservation.

x. The Structure of the State Preservation Authority. Historic preservation functions are often scattered among various state agencies to whose principal functions they are incidental. The state highway authority, the state park authority, the state fine arts commission, and others may engage in preservation functions quite independently of one another. Assuming the need for a coordinated program, can it best be accomplished by the assignment of all preservation functions to a central authority dealing exclusively with the subject, or is it more feasible to accept a diffusion of preservation powers, coordinated by a single agency? Should the state authority be a state department or agency, or may special powers be conferred on a quasi-private corporation receiving state support? ${ }^{9}$ Should preservation functions be assumed by environmental control authorities that are appearing with increasing frequency in the structures of state governments? ${ }^{10}$

2. Functions of the State Preservation Authority. Traditionally, state historical societies have been authorized to operate and maintain state-owned historical landmarks and museums. It seems clear that their powers must include the capacity to acquire historic property by gift, purchase, devise or bequest, or by eminent domain. The possession of the power of eminent domain may be critical when property is in imminent danger of destruction. What additional powers are appropriate? Adequate state services appear to include establishing uniform criteria for preservation, advisory and technical assistance to state agencies and local societies, taking inventories and maintaining registers of designated historic sites within the state, acquisition of easements or other limited property interests in historic sites and adjacent property, ${ }^{11}$ and power to contract and cooperate with the United States and with local governments and private enterprise concerning preservation objectives. Drafters of a statute providing a state preservation program may also wish to consider a program of financial assistance for counties and municipalities engaging in historic preservation programs, ${ }^{12}$ and a system of subsidies or tax relief for privately owned historic sites.

\footnotetext{
- See Ohro Rev. Cone ANN. $\$$ I49.30 (r969).

${ }^{10} \mathrm{See}$ N.J. Stat. AnN. § I3:IB-I5.128 (Supp. 1971).

${ }^{11}$ See text accompanying notes $45-51$ infra.

${ }^{12}$ See text accompanying notes 52-66 infra.
} 
3. Enabling Legislation. Local governments derive their powers from the state. While the extent of home rule powers varies from one state to another, it can be assumed that most preservation activity by local government has its basis in a grant of power by the state legislature. The objectives of such legislation vary. Local governments may be empowered to acquire, own, manage, and support historic sites as public facilities; or they may be authorized to develop standards, controls, and procedures designed to facilitate the preservation of privately owned landmarks. Special preservation powers may be expressly conferred on certain named municipalities within the state, on all local governments of a kind or class, or the power may be included in broader grants of power to control private property. ${ }^{13}$ The grants of power vary widely in scope. Local governments may be empowered to acquire and maintain historic property, to enact historic zoning ordinances, to create historic districts and commissions, to regulate external features of historic buildings, to issue bonds and levy taxes for historic preservation purposes, and to perform other relevant functions.

Historic preservation is one of the concerns of the Model Land Development Code under study by the American Law Institute. The proposal would empower the local land development agency to designate landmarks or districts of special historical, archaeological, architectural, or scenic significance, and to control development consistent with the significance of the landmark and the welfare of the community. ${ }^{14}$

\section{II}

\section{Features of Recent Preservation Legislation}

The comments in this section illustrate some of the particular concerns and approaches reflected in historic preservation legislation enacted during the past decade. The mention of particular states should not be taken as excluding the possibility of similar legislation elsewhere. The effort is not aimed at surveying the field, but at identifying some of the current trends.

\section{A. Surveys and Registers of Historic Landmarks}

The National Historic Preservation Act of $1966^{15}$ empowers the Secretary of the Interior to maintain the National Register for the listing of districts, sites, buildings, structures, and objects significant in American history, architecture, archaeology, and culture. He is further empowered to grant funds to qualifying states to prepare comprehensive statewide historic surveys as well as to establish a program of matching grants-in-aid to states for historic preservation projects. This encouragement by Congress has evoked evidence of substantial state interest in initiating

\footnotetext{
${ }^{13}$ MORRISON I2-I5.

14 Amertcan Law Institute, Model Land Development Code $\$$ 2-208 to 2-209 (Tent. Draft No. 2 , 1970).

${ }_{15}^{16} 6$ U.S.C. $\$ 470$ et seq. (1970).
} 
surveys designed to produce nominations for entry in the National Register as well as to provide the basis for a state register of landmarks.

A statewide survey of historic landmarks is a basic ingredient and probably an indispensable first step in a coordinated preservation program. This has long been recognized in Britain. ${ }^{16}$ Before preservation can be meaningful, landmarks must be authoritatively identified as worthy of preservation. Thus, the list of historic properties, compiled in an accurate survey, is the keystone to a successful preservation program. The British have found it appropriate in preparing their lists of historic properties to classify structures according to their cultural significance. Britain has established two main classes of properties and a supplementary third class for reference. The first class consists of buildings which should not be destroyed except for the "greatest necessity." The second class is made up of buildings which have a "good claim to survival." The third class is composed of structures which merit consideration, but which occur with such frequency that their inclusion would not be administratively feasible. ${ }^{17}$ This treble classification system makes proper identification more precise and enables the limited resources of government to be assigned to particular projects according to their merit as objects of preservation.

Since federal matching funds are available for such surveys, ${ }^{18}$ the suggested state action would seem to be the designation of an appropriate state agency to conduct a statewide historical property survey and to apply for the available federal funds. Presumably some state agencies have sufficient general powers to participate in the program without special legislative authorization. In other instances, legislation has been deemed proper. The acts mentioned hereafter are illustrative.

The New Mexico Cultural Properties $\mathrm{Act}^{19}$ creates a Cultural Properties Review Committee to which is assigned the primary function of identifying cultural properties and advising upon the protection and preservation of these properties. Among the specific powers conferred on the committee are the power to determine criteria,

\footnotetext{
${ }^{16}$ Green, Planning in Great Britain-A Series. Part VI: Preservation of Historic Buildings, 3I PopULAR GovernMent Ig (March, I965): "These basic ingredients-(a) listing of important buildings, (b) requiring that notice be given in advance of their demolition or alteration, (c) use of preservation orders to bar demolition or alteration, (d) acquisition of particular sites, and (e) grants to assist in maintenance of particular buildings-initially constituted a preservation program for a selected few buildings and monuments of extraordinary importance. But the same ingredients make up the current programs for dealings with a much broader range of buildings."

${ }^{17}$ Id. at 20 (quoting from Minister of Local Government and Planning, in his report Town AND Country PlanNing, I943-I95I).

${ }^{18}$ I6 U.S.C. $\$ 470(a)(1970)$ provides:

"(a) The Secretary of the Interior is authorized-

(I) to expand and maintain a national register of districts, sites, buildings, structures, and objects, significant in American history, architecture, archeology, and culture, hereinafter referred to as the National Register, and to grant funds to States for the purpose of preparing comprehensive statewide historic surveys ...

(2) to establish a program of matehing grants-in-aid to States for projects having as their purpose the preservation for public benefit of properties that are significant in American history, architecture, archeology, and culture ...."

${ }^{10}$ N.M. STAT. $\$ \S 4-27-4$ to -16 (Supp. 1969 ).
} 
to prepare and maintain a New Mexico register of cultural properties, to prepare and keep proper documentation of the historic or other significance of listed properties, to inspect such properties to insure proper cultural and historical integrity and proper maintenance, to specify repairs or other action to be taken to correct nonconforming practices, to enact regulations pertaining to preservation and maintenance, and to perform a wide variety of similar services.

Recent Arkansas legislation designates the Arkansas Planning Commission as the agency of that state to coordinate and implement a statewide historical preservation program, and to implement in conjunction therewith provisions of the National Historic Preservation Act of $\mathrm{x} 966^{20}$ The planning commission is given broad powers to plan and to cooperate with federal and other state agencies in the accomplishment of the objectives of the federal act. The act authorizes the governor to appoint such committees as he shall deem necessary for the purposes of reviewing and validating those districts, sites, buildings, structures, and objects significant in historical, archaeological, architectural, and cultural preservation which may be recommended for inclusion in the National Register.

The New Jersey Register of Historic Places is established in the Division of Parks, Forestry, and Recreation of the Department of Environmental Protection. It consists of a permanent record of areas, sites, structures, and objects within the state determined to have significant historical, archaeological, architectural, and cultural value. ${ }^{21}$ The Commissioner of Environmental Protection, with advice and recommendations of the Historic Sites Council, is authorized to establish criteria for receiving and processing nominations and for approval of areas, sites, structures, and objects, both publicly and privately owned, to be included in the register along with appropriate documentation as well as to provide for the public identification of such historic places by appropriate plaques or documentation. ${ }^{22}$ State funds may not be expended for the acquisition, preservation, or maintenance of a historic place unless it has been approved for inclusion within the register. ${ }^{23}$

In 1969 the legislature of Hawaii created the Hawaii Foundation for History and the Humanities. ${ }^{24}$ The foundation's broad functions include cooperation with state agencies in reviewing surveys and plans for preservation and approving nominations for the National Register. By earlier legislation Hawaii had established a comprehensive program for historic preservation, including the establishment and maintenance of a register of historic areas. ${ }^{25}$ Ohio, by an amendment passed in 1967 , authorized the Ohio Historical Society, a nonprofit corporation chartered by the state, to devise criteria for the designation of historic places and to take an inventory, in cooperation with the Ohio Arts Council, of significant designated and

\footnotetext{
${ }^{20}$ ARK. Stat. ANN. \$ 8-got (Supp. T969).

${ }^{21}$ N.J. Stat. ANN. $\$$ I3:IB-r5.128 (Supp. I97I).

${ }^{22}$ Id. $\$ 13: x \mathrm{~B}-15.129$.

${ }^{28} I d$. $\$$ I3:IB-I5.I30.

24 Hawail REv. Stat. \$6-I6.I (Supp. I970).

${ }^{25}$ Id. $\$ 6-\mathrm{I}$ (a) (Ig68).
} 
undesignated state and local sites and to keep an active registry of all designated sites within the state. ${ }^{26} \mathrm{~A}$ historic site preservation advisory board, consisting of fifteen members reflecting a wide range of interests, was created to assist in the program. ${ }^{27}$ The Kentucky Heritage Commission was directed in 1966 to prepare and maintain an inventory of Kentucky's historic buildings, sites, structures, and other landmarks and list on an official roll those such landmarks which possess statewide or national significance. ${ }^{28}$ The Mississippi Act which abolished its state historical commission and transferred its duties and powers to the Department of Archives and History directed that agency to make a survey of buildings of all types throughout the state which are in danger of destruction or without proper care and which in the opinion of the board of trustees should be preserved for historical purposes. Power to cooperate with the United States and to accept grants from any agency of the United States to accomplish the purposes of the act is expressly conferred. ${ }^{29}$

Further enumeration is probably not profitable. Sufficient illustrations have been given to demonstrate a serious purpose on the part of state governments to identify and plan for the preservation of their cultural monuments. The procedures and criteria for entry on the state register are generally developed in the discretion of the agencies responsible. Guidelines for the recording of historic landmarks, however, are available from the National Park Service. ${ }^{30}$

\section{B. Enabling Legislation-Historic Districts}

The preparation of an inventory of places worthy of preservation is only an intermediate objective. Further legislation is needed to define powers and assign responsibility for carrying preservation programs forward. In view of the local concerns inherent in most preservation programs, these powers and responsibilities are most appropriately vested in local governments. While the idea of legislation providing for local autonomy in preservation is not of recent origin, a consideration of the general patterns of enabling legislation, and ordinances enacted pursuant to that legislation, may be relevant to present concerns. Here, as elsewhere in state preservation law, the range of variation is wide.

One state approach to local preservation has been to use special laws to empower particular municipalities to engage in landmark preservation. Illustrative state statutes are those of Louisiana, Massachusetts, and North Carolina. Louisiana authorized the city of New Orleans to take steps to insure the preservation of the French Quarter or Vieux Carre district by constitutional amendment. The Massachusetts

\footnotetext{
${ }^{20}$ Ohro Rev. Code ANN. $\$ 149 \cdot 30$ (1969).

${ }^{37}$ Id. \$ I 49.30r.

${ }^{28} \mathrm{Kx}$. REv. Stat. $\$$ I7r.38I (Ig69).

${ }^{20}$ Miss. Code ANN. $\S 6$ I8I (Supp. 1970).

${ }^{30}$ For an excellent review and explanation of how to conduct a historic preservation survey, see $H$. McKee, The Historic American Bumbings Survey, Recording Historic Burdings (U.S. Dep't of the Interior, Nat'l Park Service I970).
} 
legislature has adopted a series of historic district acts to preserve specific areas. Since 1959, North Carolina has created historic commissions for several of its cities. Texas and Connecticut have also enacted legislation authorizing historic preservation in specific areas and municipalities. A larger group of state statutes are of general application and authorize all municipalities to enact historic zoning ordinances, to create historic districts, and to engage in historic preservation activity. Still another group of states has authorized municipalities to take note of the needs for historic preservation in the administration of its general laws relating to the regulation and use of private property. ${ }^{31}$

In some instances local governments have not found express state authorization necessary to initiate preservation programs. The earliest efforts of Charleston, South Carolina, to accomplish historic preservation objectives were apparently undertaken under the provisions of its general zoning ordinance. ${ }^{32}$ In Santa $\mathrm{Fe}$, New Mexico, the Old Historic Santa Fe District was created without express legislative authority. The district was validated by the Supreme Court of New Mexico in the case of Santa Fe v. Gambleskogmo, Inc. ${ }^{33}$ in which the court found that the general statute authorizing cities to make regulations and restrictions in accordance with a comprehensive plan to promote the health and general welfare was sufficient to authorize the action taken ${ }^{34}$ On the other hand, municipalities ought to be more comfortable when they act within a framework of law specifically authorizing historical preservation activities. The criteria imposed in such legislation should probably be quite broad inasmuch as there are many reasons for preservation of structures and sites: architectural importance, association with historic events and personages, uniqueness in setting or design, and indeed, age alone may be a valid criterion for preservation. The statute may be very general and broadly worded such as the 1965 New Mexico Historic District Act which simply authorizes counties and municipalities to enact and enforce zoning ordinances, to expend public funds and acquire property by eminent domain, and otherwise to accomplish preservation objectives; ${ }^{35}$ or the enabling act may confer carefully defined authority and powers, such as the Arkansas Historic Districts Act which sets forth detailed procedures for the municipal designation of landmarks and specific standards to guide the local commission in carrying out its responsibilities. ${ }^{36}$ Both types of state legislation accomplish intended objectives, but the specificity of the Arkansas statute

\footnotetext{
${ }^{31}$ Morrison 12-15 summarizes the statutes and constitutional provisions enacted prior to 1965 .

32 See McGee, Legal Aspects of Preservation, Hisroric PReservation, Jan.-Mar., 1971, at 14-I5.

${ }_{73}^{8 a}$ N.M. 410,389 P.2d I3 (I964). This case involved the historic district of Santa Fe, New Mexico, in which window panes were limited in size to no more than 30 inches square. The window pane dividers or mullions were removed without the city's approval, in violation of the ordinance.

${ }^{34} 73$ N.M. at 415,389 P.2d at $I_{7}\left(I_{964}\right)$. The court found adequate authority in the broad language of N.M. STAT. ANN. $\$ \$ I_{4-28-9}$ to -II (I953), and particularly in the language of $\$$ I4-28-II which authorizes cities to make "regulations and restrictions" in accordance with "a comprehensive plan to promote the health and general welfare."

${ }^{35}$ N.M. STAT. ANs. \$§ I4-2I-I to -5 (Ig68).

${ }^{80}$ ARK. STAT. ANN. \$\$ r9-500I to -50II (Ig68).
} 
leaves little guesswork for local authorities and assures procedural uniformity throughout the state and compliance with basic standards for control. Whether such limitations are necessary or desirable is a matter for legislative determination.

Historic preservation programs are often implemented through powers conferred on local governments to create historic districts and to vest functions relating to preservation within the district in a local historic commission. The 1970 Michigan historic district act is representative of recent enactments of this kind. ${ }^{37}$ The typical historic commission is responsible for designating historic properties and for carrying out policies declared in the state enabling act and local ordinance. Usually the members of the commission are appointed by the governing body of the municipality or nominated from concerned professional groups. The commission may be composed of architects, historians, lawyers, and other representative citizens of the districts to be preserved. The commission may be empowered to employ a professional staff, maintain liaison with experienced and interested architects, and provide advisory and consultative services. One of its roles may be to forestall the ripening of potential problems. A continuous program in preventive field work in historic areas will prevent destruction by deterioration and promote compromise and viable alternatives to demolition. Prior consultation as to workable alternative solutions before destruction becomes imminent may enable the commission to prevent crises which sometimes occur when the landowner has determined upon a plan of alteration or removal. This approach should be helpful to the efficient and successful operation of a landmark preservation program because it induces voluntary compliance with the law-the foundation of any regulatory program.

In addition to more general powers, it would appear that an effective commission should be authorized to use the power of eminent domain, to acquire restrictive easements, to review and regulate construction and demolition activity, and to enforce zoning and architectural controls in the historic districts.

In a sense, the commission's power to regulate architectural features is superficial $^{38}$ as its control can be exercised only over exteriors of landmarks. Regulations are generally not imposed over the design or use of a building's interior and the municipality cannot require maintenance or repairs beyond that generally imposed by the city's building, fire, and health regulations. One problem often not foreseen is the recalcitrant property owner who would rather let his building rot than restore it, thus forcing demolition. To cope with this situation a city may need an antineglect ordinance giving the landmarks commission authority to prevent demolition by neglect. ${ }^{39}$

\footnotetext{
${ }^{37}$ Mich. CoMp. Laws ANN. $\$ \$ 399.201-.212$ (Supp. I97I).

${ }^{38}$ Address by Albert B. Wolfe, Conservation of Historical Buildings and Areas-Legal Techniques, Proceedings of Section of Real Property, Probate and Trust Law, American Bar Association, Chicago, Ill., Aug. $12-13$, 1963 [hereinafter cited as Wolfe].

${ }^{30}$ The City of New Orleans requires structural soundness of buildings in the Vieux Carre section under criminal penalty. This ordinance can be supported by the public policy to protect the health and safety of the community.
} 
Municipal preservation activities must be concerned not only with preserving the existing structures, but also with preventing new structures from destroying a historic setting. Changes within the historic district should be permitted only when they are planned to strengthen the character of the area. Limited controls over new buildings and historic preservation areas can be accomplished in voluntary programs among the property owners who agree to an overall plan of type of architecture, but better protection may be provided by regulations setting appropriate standards in historic zoning ordinances which require new structures to conform with the existing style.

Constitutional considerations are highly relevant to the work of the landmarks commission. Its powers must be exercised in a legal framework which prescribes definite standards to govern the application and enforcement of the law. Thus, the ordinance must specify architectural standards or styles to serve as criteria to guide the commission in administering the preservation program. For example, Charleston's ordinance of x93 called for a board of architectural review "to consider proposals affecting exterior architectural features which are subject to public view from a public street or way" in order to prevent "developments obviously incongruous to the old historic aspects of the surrounding." in terms of specific styles and techniques but in terms of harmony with the visible aspects of existing structures. The standard of "obviously incongruous" has been used by many other municipalities. The Massachusetts Supreme Judicial Court, in an advisory opinion, found Nantucket's limitation which prevented developments "obviously incongruous to the historic aspects of the surroundings" to be sufficiently definite. ${ }^{41}$

Ordinances not only define the commission's powers and limitations, but they must prescribe procedural standards. Designations of private property which result in limitations on use or control, whether individual properties or historic districts, must observe standards of due process. In either instance, minimum procedural safeguards require notice to the owner or occupant, opportunity for a hearing or remonstrance, and review by the governing body of the municipality with ultimate recourse to the courts.

When the historic district has been established and its boundaries identified, property within the district becomes subject to the special historic district regulations. The regulations bar property owners from construction, alteration, or demolition

"0 Charleston, S.C., Code of Charieston, art. $x$, ch. 49, $\$ \$ 42-46$.

1 Opinion of the Justices, 333 Mass. 773, 780-8x, r28 N.E.2d 557, 562 (r955). The court stated: "We think the requirements of the proposed act are not too indefinite or lacking in sufficient standards. The act does not require anything to be done to existing structures with the possible exception of signs (\$6). With the same possible exception, it applies only to exterior architectural features subject to public view from a public place $(\$ 4)$. It does not apply to details of design or sizes of buildings or interior arrangements of building features not subject to public view, and requirements by the commission must be limited to the preventing of developments 'obviously incongruous to the historic aspects of the surroundings' $(\$ 8[c])$. This last provision is apparently intended to prevent decisions based upon peculiar individual tastes. All provisions must be interpreted with reference to the main purposes of the act." 
activity within the district without prior approval by the commission. The regulations may require a written notice of intent to alter or demolish and permit such action on the commission's determination that the proposed changes are appropriate. Violations of the regulations are usually subject to punishment by fine or imprisonment.

It is probably important that the municipal landmark commission be designated a governmental agency. This is necessary in order for municipalities to acquire federal funds available through the Department of Housing and Urban Development. ${ }^{42}$ It is equally important from the operational viewpoint for such a designation adds legitimacy to the landmark preservation program. A full-fledged agency with a professional staff can be on equal terms with other city offices when confronted with adverse affects of zoning, streets, and city planning. As a city agency, the commission can negotiate more effectively with officers responsible for urban renewal programs. Unwanted structures can be removed and replaced with buildings which will accentuate and reinforce the style of the landmarks preserved, thus enhancing the area's historic character.

\section{Acquisition of Property Interests-Easements}

To foster the public interest in historic preservation, power should be vested in the historic authority to acquire and hold title or other interest in historic property. Most such agencies have the power to acquire property by gift or purchase. Fewer may use the state's power of eminent domain to acquire such property. As an illustration of the latter group, the Virginia code vests in the Attorney General the power to use the Commonwealth's power of eminent domain to preserve historical monuments or memorials when it appears to him to be in the public interest to do so. ${ }^{43}$

Use of the power of eminent domain may assist the statute and its municipalities in taking direct preventive action when important historic properties are in danger of being destroyed. The Virginia statute which authorizes boards of supervisors in certain counties to acquire historic properties admonishes that the power of eminent domain shall not be used for this purpose unless "the historic value of such property is about to be destroyed." 44 Extensive public ownership of historic property is probably unwise because it reduces the community tax base and burdens the public budget with costs of acquisition and maintenance. Furthermore, it usually results in preservation of isolated buildings as museums and similar facilities. Economic considerations suggest the desirability of inducing private owners to preserve their property for use in economically productive enterprises, thereby creating more individual interest in preservation and mitigating the burden of cost to the government.

As a variation on the acquisition of property for public use, several recent acts

${ }^{42} 42$ U.S.C. $\$$ I50od-x (1970).

${ }^{4}$ VA. CODE ANN. \$ I0-I45.I (Supp. I970).

¿VA. CODE ANN., \$ I5.I-503-I (Supp. I97I). 
authorize the taking of restrictive easements. A negative easement over the facade of the structure, investing the public with a property interest in the building's exterior without disturbing private ownership and control of the interior prevents the owner of the structure from altering or demolishing the exterior without the prior consent of the agency controlling the easement. The restrictive easement has several advantages over outright ownership. It costs less to acquire an easement than to purchase the fee title to property, it does not need the support of broad historic district legislation, and it enables the preservation of particular structures in a relatively simple manner.

A I970 amendment in Maryland defines property subject to acquisition by the Maryland historical trust as including "scenic, architectural or facade easements on buildings or structures." ${ }^{35}$ A recent Oregon enactment authorizes the state, or any county, city, and park or recreation district to acquire conservation or scenic easements by means other than eminent domain. ${ }^{46}$ Conservation or scenic easements are defined as "an aggregation of easements, covenants or conditions running with the land, designed to preserve or maintain all or part of the natural or existing state of recreational, cultural, scenic, historic or other appropriate places of public significance." ${ }^{\text {"7 }}$ The Virginia Historical Commission is authorized to acquire registered landmarks, sites, easements, and interests therein..$^{48} \mathrm{Also}$, in Virginia certain counties are authorized to acquire in any legal manner any historic area, landmark, building or structure, land pertaining thereto or any estate or interest therein, which in the opinion of the board of supervisors should be acquired and maintained. ${ }^{40}$ Indeed, it seems reasonable to infer that any general grant of power to the historic district to acquire property would imply the power to acquire easements for the purpose of maintaining the exteriors of historic structures.

Certain practical problems may be involved in the management of individual properties subject to public easements for preservation purposes. The arrangement necessarily involves a division of ownership between parties whose interests may not necessarily be compatible. Also present is the question of valuation of the part of the property taken under the easement. Unless a facade easement is donated for historic purposes, there must be compensation for its having been taken. In condemnation cases, the standard for compensation is the amount of the owner's loss, not the condemnor's gain. The owner's loss is measured by the value of the property taken. Market value ordinarily constitutes just compensation, but for the facades of venerable buildings the market is very limited. Similar problems may arise in adjusting valuations for tax purposes.

Restrictive easements and covenants have been used for many years by the

\footnotetext{
${ }^{45} \mathrm{MD}$. ANN. CODE art. 4I, $\S \mathrm{I} 8 \mathrm{IA}$ (I97I).

${ }^{48}$ Ore. Rev. Stat. \$271.720 (1969).

${ }^{47}$ Id. \$27I.7IO.

${ }^{49}$ VA. CODE ANN. $\S 10-138(e)$ (Supp. $\left.x 970\right)$.

${ }^{18}$ See note 44 stspra.
} 
British National Trust to protect buildings as well as open space. ${ }^{50}$ Richmond, Virginia, has used an historic landmark marker system to acquire restrictive easements on historic property. The marker is offered as consideration for a covenant running with the land. Thus, the city obtains a permanent interest in the property prohibiting the landmark owner from removing the marker, demolishing the building, or altering the facade without municipal approval. If application is made and denied, a demolition permit will not issue for six months during which the city may determine whether it shall condemn or otherwise acquire the structure in order to expedite its preservation. ${ }^{51}$ Similar marker programs are used elsewhere without provision for a restrictive covenant on the land. A successful marker program may instill pride in the landowner and induce preservation without municipal intervention, thus creating a cooperative historic preservation program.

\section{Economic Inducements to Preservation-Tax Concessions}

State and local tax laws may be used to provide inducements for preserving existing structures as a form of indirect public subsidy. Historic commissions and property under their control are usually declared tax exempt. ${ }^{52}$ Presently federal and state income tax laws encourage landowners to donate property to charitable or educational organizations and historic preservation societies by allowing deductions for the value of the property donated. ${ }^{53}$ Logical extensions of this policy, encouraging landmark owners to maintain their properties as landmarks rather than to demolish or alter them, is reflected in several recent acts of legislatures.

The New Mexico Cultural Properties Act of Ig69 exempts privately owned properties on the official register from "local city, county and school property taxes" to the extent of approved restoration, preservation, and maintenance expenses each year and provides further that "amounts expended in a given year may be carried forward to as many as ten ... subsequent years for the application to property taxes ...."54 A I969 Connecticut law permits any municipality by ordinance to provide for the abatement in whole or in part of real property taxes on structures of historical or architectural merit. The determination as to whether property is available for classification as historically or architecturally meritorious is made by the municipality or may be delegated to local, private preservation or architectural groups. The tax

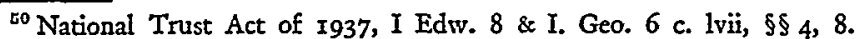

${ }^{51}$ Richmond, VA., CITY CODE $\$ \S 2$ T-23 to $2 x-27$ (I968).

${ }^{52}$ N.J. Stat. ANN. $\$ 54: 4-3-3.52$ (Supp. I97 ) states: "Any building and its pertinent contents and the land whereon it is erected and which may be necessary for the fair enjoyment thereof owned by a nonprofit corporation and which has been certified to be an historic site to the Director of Taxation by the Commissioner of Conservation and Economic Development as hereinafter provided shall be exempt from taxation."

${ }^{53}$ For the federal charitable contribution deduction see INT. REv. CoDE of 1954, §I70. For an example of authorized state deductions see ArA. CoDE tit. 5I, $\$ 385$ (J) (Supp. I970).

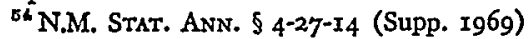


abatement authorized upon property which is so classified is available when it is shown to the satisfaction of the municipality that the current level of taxation is a material factor which threatens the continued existence of the structure, necessitating either its demolition or remodeling in a manner which destroys the historical or architectural value. If, after abatement of taxes, the structure is demolished or remodeled in a way which destroys its architectural or historical value, the owner must pay the municipality an amount equal to the total amount of taxes which have been abated under the provisions of the act. The act further provides that in the discretion of the Connecticut Historical Commission the state may contract with the municipality for state financial assistance to the extent of the taxes abated. The contract between the state and the municipality provides for payments to be made annually at an amount equal to the difference between the tax that would be paid on the property if there were no abatement and the tax actually paid, and that in consideration of such grants-in-aid the municipality shall abate taxes to the agreed amount during the period of contract. If an owner repays the tax abatement to the municipality, the repayment shall be returned to the state..$^{55}$ Other states, including Illinois and Virginia, offer private landmark owners tax relief in somewhat less specific terms. Instead of allowing reduction of property taxes by the amount of preservation expenditures, Illinois simply declares the depreciation resulting from landmark designation shall be deducted from the valuation of the property for tax purposes. $^{58}$ The Virginia statute states that designation as a landmark "shall be, prima facie, evidence that the value of such property for commercial, residential, or other purposes is reduced by reason of its designation." ${ }^{57}$ New York's enabling act, one of the shortest, broadly defers specific taxing procedures to municipalities, stating that where municipal restrictions concerning historic preservation constitute a taking of private property, the city "shall provide for due compensation, which may include the limitation or remission of taxes."

The current session of the legislature of North Carolina has had under consideration legislation which would authorize qualified buildings and structures of great historical and architectural significance to be classified separately and taxed by local taxing units at twenty-five per cent of the rate levied for all purposes upon real estate and tangible personal property in the taxing district. Only the buildings, and not the land upon which they are situated, would receive the benefit of the tax reduction. Annual application by the owner and certification as to the historical or architectural merit of the building would be required for continued participation in the tax benefit. Another North Carolina proposal would authorize deductions from state income tax, up to twenty per cent of adjusted gross income

\footnotetext{
${ }^{58}$ CoMp. Gen. Stat. Ans. $\$$ 12-127a (Supp. T971).

${ }^{50}$ ILI. ANn. Stat. ch. 24, \$ II-48.2-6 (I970).

${ }^{57}$ VA. CODE ANv. $\$$ IO-I39 (Supp. I970).

${ }^{58}$ N.Y. GEN. Munic. Laws $\$ 96-a$ (McKinney Supp. 1970).
} 
over a period of five years, for costs of restoration and repairs to buildings and structures of historical and architectural significance. ${ }^{59}$

The Oregon statute provides that real property subject to conservation or scenic easements shall be assessed on the basis of true cash value of the property less any reduction of value caused by the conservation or scenic easement. The easements are exempt from assessment and taxation to the same extent as any other property owned by the state, county, city, or park and recreation district. ${ }^{60}$

An interesting approach to financing preservation activities is found in Great Britain's "Country House" scheme. ${ }^{61}$ Under this plan a landowner may donate his historic property, with an endowment to finance future maintenance, to the British National Trust which allows the donor and his heirs thereafter to live in the house rent-free, provided that they allow public access to the property and the main rooms of the house for a specific number of days per year. This donation removes the property from the landowner's estate, thus escaping Britain's high estate taxes upon death. The plan also exempts the endowment fund income from taxation. A plan with similar characteristics is presently in use in the United States. The Society for the Preservation of New England Antiquities, a private charitable corporation originally chartered by a Massachusetts Special Act in $1910,{ }^{62}$ has been authorized to acquire and hold properties for preservation exempt from local real estate taxes. The Society has been granted similar powers by other New England states, enabling it to acquire properties throughout the entire New England area. The Society allows "curators" or "custodians" to live in its houses with the agreement that they will properly maintain them, keep certain portions open to the public at specific times, and contribute to the costs of repair and maintenance. ${ }^{63}$

Perhaps other financial inducements can be offered in the form of low-cost loans for historic property owners for preservation of properties or, in the alternative, to finance relocation of businesses if they agree to sell for a low price to the preservation commission. If the community believes the structure is worth preserving, it might provide financial assistance through revenue bonds or through a federal or state credit agency which could guarantee commercial bank loans to landmark owners at low interest rates, similar to existing programs for low-cost housing.

Although the focus of this article is on state legislation, it may be proper to look briefly at some of the innovative thinking that is evident in the city halls of the great cities where much of the battle for preservation is localized. New York City has devised a unique form of economic inducement to preservation which is directly linked to the city's power to impose restrictions. Under the city's preservation pro-

\footnotetext{
${ }^{50}$ Letter from Robert E. Stipe to Paul E. Wilson, Apr. I, I97r.

${ }^{\circ 0}$ Ore. Rev. Stat. $\$ 271.740$ (I969).

${ }^{01}$ See Green, supra note 16 , at 28.

${ }^{02}$ Wolfe 3.

${ }^{8 x} 1 d$. at 4 .
} 
gram, owners of properties deemed historic landmarks by the Landmarks Preservation Commission must apply to the Commission for a permit before demolishing or significantly altering their structures. In order to obtain the permit the owner must convince the Commission that at the time he files his request the building and site, as it exists, are incapable of earning a reasonable economic return. The ordinance defines "reasonable return" as six per cent of the assessed valuation of the building and its site. ${ }^{64}$ This guaranteed rate of return is critical in the New York City preservation program because it imposes an automatic restriction on the Commission's power. The landmark owner is prohibited from demolishing or altering the exterior of his structure so long as it is earning the statutory rate of return. If the Commission determines an historic landmark is incapable of earning the six per cent annual return, plans are devised to preserve the structure. Any alternative plan must assure the owner a six per cent return. To achieve this objective the Commission is empowered to remit or abate real estate taxes with the approval of the city's Board of Estimate. If the landmark owner rejects all plans, the Commission may save the structure by purchase or condemnation.

The concept of transferability of the right to develop air space over particular parcels of real estate has produced innovative compensation techniques to induce preservation in large cities. In I968, New York City amended its zoning ordinance to allow the landmark owner to transfer the unused air space over his landmark to adjacent lots. ${ }^{65}$ The landmark owner profits from the transfer of his excess development rights, and the owner of the adjoining lot-who may be the landmark owner himself-can, by reason of the transfer, build a structure up to but not exceeding a twenty per cent increase over the bulk usually permitted. This compensation plan allows the building to remain on the tax rolls with any reduction in landmark lot taxes offset by the increased tax of the adjoining lot. The landmark owner's 'transfer of rights is irrevocable so that if the landmark is ever destroyed, no sub. sequent building may be developed above the area as reduced by the transfer. This technique not only enables a landmark owner to take advantage of monetary gain from rising neighborhood property values, but also assures no future development above the landmark. As unlikely as this seems, developers have recently proposed to erect a building over New York City's Grand Central Terminal. This landmark would be technically preserved but the entire setting would be lost.

In a recent issue of the New York Times, a Chicago proposal based on the transferability of air rights is described as one that "surges briskly past New York." The law would create special districts, such as the Loop Preservation District, and

\footnotetext{
64 "The statute provides that the 'net annual return' shall be that amount which is the excess of earned income yielded by the property over the operating expenses of the property, excluding mortgago interest and amortization and allowances for obsolescence and reserves, but including a specified allowance for depreciation." J. Pyke, Jr., Landmark Preservation i9 (Citizen Union Rescarch Foundation 1969). ${ }^{65}$ Id. at 29 n.38.

${ }^{66}$ Huxtable, $A$ Solid Dross City, N.Y. Times, Mar. I4, I971, at 16, col. 5.
} 
the air rights over landmark structures acquired from owners by tax benefits or other means would be pooled in a municipal air rights bank. The unused development rights would be sold by the city to developers within the district, subject to strict controls, and the funds derived from the sales would be used to maintain landmarks.

\section{E. Limitations on Competing Public Projects}

The activities that threaten historic preservation are not exclusively the works of commerce and private industry. Frequently, the destruction of landmarks results from efforts to respond to other public interests. During the past decade historic neighborhoods and structures have been frequently placed in jeopardy by urban renewal, highway construction, and other federally-supported or assisted programs. An awareness of the threat posed by public construction motivated Congress to provide in section 106 of the National Historic Preservation Act that the head of any federal agency with jurisdiction over any federal or federally-assisted undertaking should, prior to approving the expenditure of public funds on the program, take into account the effort of the undertaking on any historic property located on the National Register. He must also afford the Advisory Council on Historic Preservation a reasonable opportunity to comment with regard to such undertaking. ${ }^{67}$ In view of the congressional policy, it may be appropriate for state legislatures to consider similar protection against encroachment by state, county, and municipally funded projects. A few have done so. In 1970 the New Jersey legislature declared:

The State, a county, municipality or an agency or instrumentality of any thereof shall not undertake any project which will encroach upon, damage or destroy any area, site, structure or object included in the Register of Historic Places without application to, and prior written authorization or consent of, the Commissioner of Environmental Protection. ${ }^{68}$

Also, in I970 the legislature of Pennsylvania required that the Department of Transportation investigate the effects of any proposed new highway construction with respect to a long list of social and environmental concerns, including natural and historic landmarks. ${ }^{69}$ The Hawaii Act Relating to Preservation and Protection of Prehistoric and Historic Sites and Archeological Remains requires that before any public construction is begun, the head of the responsible agency shall determine whether the improvement will encroach upon any designated prehistoric or historic sites. When such encroachment is found, the project may not be begun until it has been approved by the Department of Land and Natural Resources with the concurrence of the governor. ${ }^{70}$ Legislation of this nature assures the landmark a hearing before its demise. It may be an important safeguard against improvident demolition.

${ }^{\circ 7}$ I6 U.S.C. $\$ 470 f$ (I970).

${ }^{88}$ N.J. STAT. ANN. \$ I3:IB-r5.I3I (Supp. I97I).

${ }^{\circ}$ PA. Stat. ANN. tit. 7I, $\$ 5$ I2b (Supp. I97I).

${ }^{70}$ HawaIr Rev. Stat. \$ 6-II (Supp. I970). 


\section{F. Protection of Archaeological Sites}

The protection of archaeological resources has been the special concern of many state legislatures. More than a dozen states have reported legislation of this kind during the past decade. ${ }^{71}$ In some instances the objectives of general historic preservation statutes include the protection of archaeological objects. The scope of other legislation is limited to the protection of archaeological sites as defined in the acts.

The provisions of: archaeological resources acts are hardly uniform, although certain features recur with a considerable amount of consistency: ( $I$ ) the acts often declare the state's interest in the preservation of all antiquities, including historic ruins, sites, artifacts, and similar places and things; (2) title to archaeological resources on public lands is vested in the state; (3) exploration and excavation on public lands is closely controlled; (4) power to issue or deny permits for field archaeology on public lands is vested in a state control agency; (5) persons or agencies eligible for permits are identified and conditions to be imposed on such permits are stated; (6) procedures for reporting archaeological finds are set out; (7) procedures for discouraging or controlling field archaeology on privately owned lands are established; (8) coordination with other activities of government and cooperation with responsible agencies is authorized; and (9) penalties are provided for unauthorized excavation or other violation.

The classes of protected items is also of interest. Among the subjects of the protection given by the Arkansas act are artifacts, including "all relics, specimens, or objects of an historical, prehistorical, archeological or anthropological nature, which may be found above or below the surface of the earth, and which have scientific or historic value as objects of antiquity, as aboriginal relics, or as archeological specimens," and sites, defined as "all aboriginal mounds, forts, earthworks, village locations, burial grounds, historic or prehistoric ruins, mines or caves, which are or may be the source of artifacts ...."72 Even broader definitions are found in the acts of states having significant underwater archaeological resources. In addition to protecting artifacts and sites, the Georgia act includes "treasure, treasure trove, ancient and abandoned ships and other similar sites and objects found on all lands owned or controlled by the State or found in the Atlantic Ocean within the threemile territorial limits of the State or within its navigable waters . . ."73 Mississippi also protects "sunken or abandoned ships and wrecks of the sea ...."T4 Texas limits

\footnotetext{
${ }^{71}$ Alaska Stat. $\$ \$ 38.12 .010-.050$ (xg68); ARK. Stat. ANN. $\$ \$ 8-801$ to -808 (Supp. I969); Colo. Rev. Stat. \$§ I3I-I2-I to I3I-I2-6 (Supp. I967); GA. Code ANN. \$\$ 40-813a to -814b (Supp. 1970); Kan. Stat. AnN. $\$ \$ 74-5401$ to -5408 (Supp. I969); ME. Rev. Stat. ANn. tit. 27, $\$ 371-74$ (Supp.

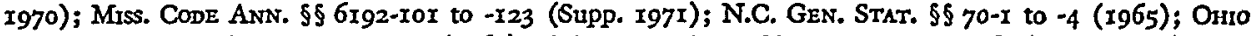
REv. CODE ANN. $\$ \$ 273.705$, .7II (I969); S.C. CODE ANN. \$\$54-32I to 54-328 (Supp. 1970); VT. STAт. ANN. tit. 22, $\$ 347-48$ (Supp. I970).

${ }^{72}$ ARR. Stat. ANN. $\$ \$ 8-801$ to -808 (Supp. 1969).

${ }^{73}$ GA. CODE ANn. \$40-8r3a (Supp. 1970).

${ }^{74}$ Miss. CODE ANN. \$6I92-I02 (Supp. I97I).
} 
its interest in shipwrecks to those which occurred prior to the twentieth century. ${ }^{75}$ Indeed, recent antiquities acts in most states having seaboards or other large state controlled underwater areas indicate an awareness of the need for protecting underwater resources.

\section{ConcLusion}

The response of state legislation to the urge for historic preservation has been varied-as varied as the states themselves and the aspirations of their people. Perhaps the only generalization that can be drawn from an examination of state preservation legislation is that current activity at the state house level reflects an interest in historic preservation and an awareness of the indispensable role of the state in accomplishing preservation objectives. Candor requires recognition that too often the awareness has come too late and the interest is unsupported by substantial com. mitment. Before the powers of state government can be used effectively to protect the cultural environment, the existence of those powers must be recognized and their extent must be defined by law. The legislative framework for effective state preservation programs is emerging in several, perhaps many, states. The impact of such legislation will be determined by its implementation.

\footnotetext{
${ }^{75}$ TEx. REv. Crv. STAT. art. 6145-9, \$ 2 (I970).
} 